Manejo y conservación de los mamíferos terrestres de Japón:

prácticas y sistema organizacional

\title{
Conservation and management of terrestrial mammals in Japan: its organizational system and practices
}

\author{
Takashi Saitoh ${ }^{1 *}$, Koichi Kaji², Masako Izawa ${ }^{3}$, and Fumio Yamada ${ }^{4}$
}

${ }^{1}$ Field Science Center, Hokkaido University, Kita 11, Nishi 10, Sapporo 060-0811, Japan. Tel: +81 11706 2590. E-mail address: tsaitoh@fsc.hokudai.ac.jp (TS).

${ }^{2}$ Faculty of Agriculture, Tokyo University of Agriculture and Technology, 3-5-8 Saiwaicho, Fuchu 183-8509, Japan (KK).

${ }^{3}$ Faculty of Science, University of the Ryukyus, Nishihara, Okinawa, 903-0213, Japan (MI).

${ }^{4}$ Forestry and Forest Products Research Institute, Tsukuba, 305-8687, Japan (FY).

${ }^{*}$ Corresponding author

\begin{abstract}
Introduction: One hundred and one native terrestrial mammalian species, excluding Sirenia, Cetacea, Phocidae, and Otariidae, inhabit or inhabited Japan, and $51.5 \%$ of them are endemic, most being forest dwellers. Four species, the wolf, the Okinawa flying fox, the Bonin Pipistrelle, and the Japanese river otter went extinct during the modern age. The relatively small extinction rate in Japan is probably because forest destruction has been limited. About two thirds of Japanese lands are still covered by forests (25.10/37.79 million ha; $66.4 \%$ as of 2011 by Forestry Agency of Japanese Government). However, the number of species that are ranked high in conservation status is not small; 5, 15, and 8 species are ranked "Vulnerable" (VU), "Endangered" (EN), and "Critically endangered" (CR), respectively. The total number of species ranked in these three categories is 28 , and the percentage $(28.9 \%=28 / 97)$ is higher than the world standard. This situation may be caused by extensive construction of artificial forests from 1950's to 1970's, during which many natural forests were cut and transformed to man-made forests.
\end{abstract}

Discussion and Conclusions: The proportion of natural forests was reduced to about $40 \%$ of the total area of forests by 2013. The most influential laws for wildlife conservation and management in Japan are the "Act on the Conservation of Endangered Species of Wild Fauna and Flora" and "Wildlife Protection and Proper Hunting Act". The Amami rabbit (Pentalagus furnessi), the Bonin flying fox (Pteropus pselaphon), a subspecies of Ryukyu flying fox (Pteropus dasymallus daitoensis), and two subspecies of the leopard cat (Prionailurus bengalensis iriomotensis and P. b. euptilurus) are conserved under the "Act on Conservation of Endangered Species of Wild Fauna and Flora", whereas the conservation of many endemic terrestrial species that are ranked high in conservation status are not implemented in Japanese laws. Recently many management practices have been developed for overabundant populations of the sika deer (Cervus nippon) and the wild boar (Sus scrofa) under "Wildlife Protection and Proper Hunting Act".

Key words: Amami rabbit, extinction rate, flying fox, forests, Leopard cat, management, Sika deer, wild boar, wildlife legislation

\section{Introduction}

Japan is a forest rich country. Therefore, most terrestrial mammals in Japan are forest dwellers (Ohdachi et al. 2009). One hundred and one native mammalian species, excluding Sirenia, Cetacea, Phocidae, and Otariidae, inhabit or inhabited Japan, and $51.5 \%$ of them are endemic on the bases of description by Ohdachi et al. (2009; Figure 1a). Of the 101 terrestrial species, the wolf (Canis lupus), the Okinawa flying fox (Pteropus loochoensis), the Sturdee's pipistrelle (Pipistrellus sturdeei), and the Japanese river otter (Lutra lutra) went extinct during the modern age. The extinction rate in Japan is small (4.0 \%) in comparison with the rate in UK ( $40.5 \%=17 / 42$ species), although both are similar 
sized island countries and have been highly industrialized. This relatively low rate is probably because forest destruction has been limited in Japan. About two thirds of Japanese lands are still covered by forests (25.10/37.79 million ha; $66.4 \%$ as of 2011 according to the Forestry Agency of Japanese Government 2013), while $90 \%$ of forests had been lost over the past 5,000 years in UK (UK Clearing House Mechanism for Biodiversity). The better situation of forests in Japan may be caused by the relatively strict forest management in the Edo era (1603-1868), the later start of industrialization (from the middle of 19th century), steep terrain preventing logging, and favorable climate for forest regeneration (see Diamond 2005 for details).

Recent status of the conservation system. Although the extinction rate is relatively small, the recent population status of Japanese mammals suggests that the sustainability of many species is not assured. The number of species that are ranked high in conservation status is not small; 5,15 , and 8 species are ranked "Vulnerable" (VU), "Endangered" (EN), and "Critically endangered" (CR), respectively, on the basis of the list made by the Mammal Society of Japan (Figure 1b). The total number of species ranked into these three categories is 28 , which is $28.9 \%$ of all extant terrestrial species (97 species). This is higher than the average for mammals in the world as a whole $(24.0 \%$ $=1103 / 4600$; IUCN). Japan, the proportion of highly ranked species is high among the Chiroptera $(42.9 \%)$ and Carnivora (25.0\%). This situation may be caused by extensive construction of artificial forests from 1950s to 1970s, during which many natural forests were cut and transformed into man-made monocultural forests. By 2013, the proportion of natural forests had been reduced to about $40 \%$ of the total area of forests (the Forestry Agency of Japanese Government 2013). In addition to the changes in forest quality, human disturbance to caves and other roost sites may be having some impacts on Chiroptera populations.

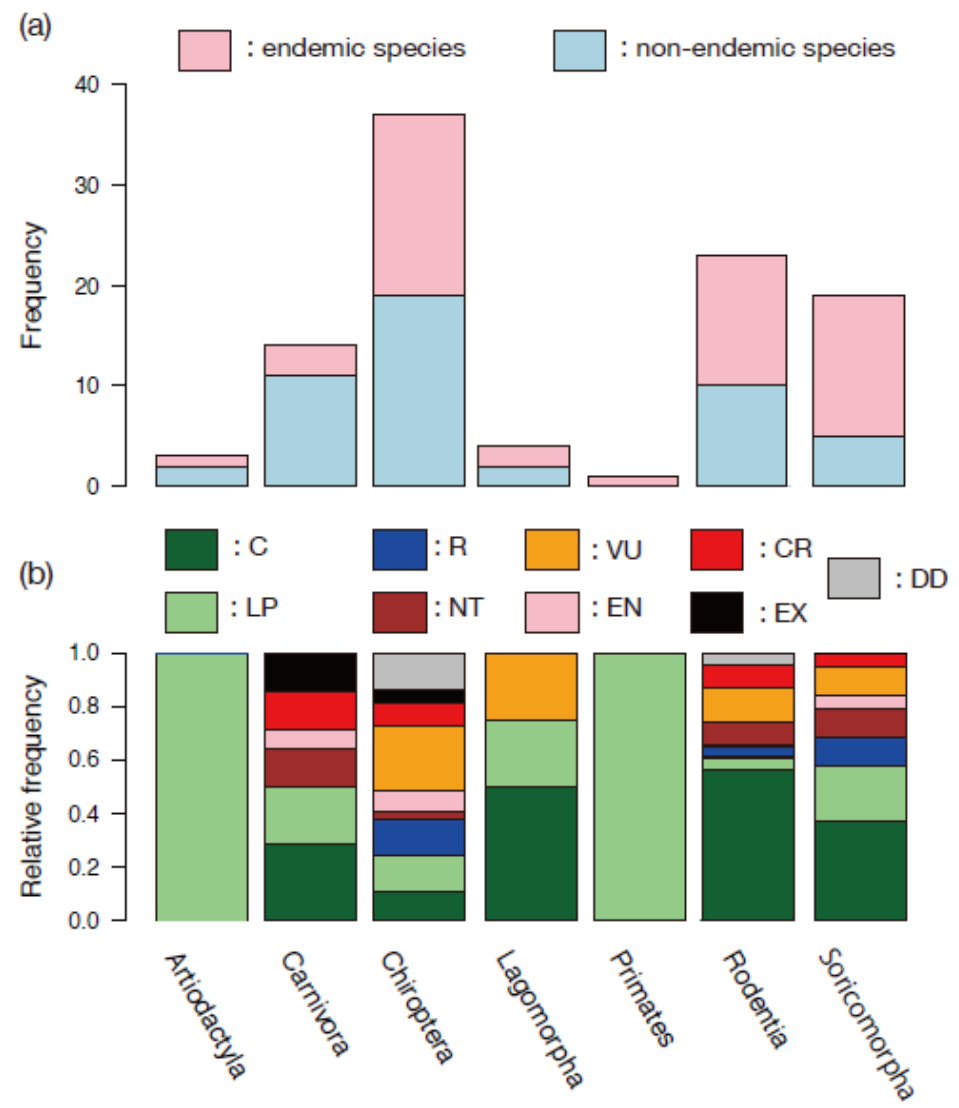

Figure 1. (a) The number of native terrestrial mammalian species in Japan arranged in seven taxonomic orders. (b) The relative frequency of species in each conservation status; C: common; LP: threatened local population; R: rare; NT: nearly threatened; VU: vulnerable; EN: endangered; CR: critically endangered; EX: extinct; DD: data deficient. 
The Japanese government has developed legal systems in order to stem the further reduction of biodiversity (Figure 2). Although the system consists of 9 laws, the most influential laws for wildlife conservation and management are "Act on the Conservation of Endangered Species of Wild Fauna and Flora" and "Wildlife Protection and Proper Hunting Act."

"Act on the Conservation of Endangered Species of Wild Fauna and Flora"

Both Japanese and English versions can be accessed through the following website:

http://www.japaneselawtranslation.go.jp. This act is aimed at ensuring the conservation of endangered species of wild fauna and flora, and requests the national government to monitor the status of wild fauna and flora species as well as to formulate and implement comprehensive measures for the conservation of endangered species. Local governments have also responsibility to formulate and implement measures for their conservation. This endangered species legislation is designated by Cabinet Order, and prohibits in principle the taking, transferring, or displaying of species so designated. The Minister of the Ministry of Environment (MOE) may designate, as "natural habitat protection area", the habitat of particular species and the area that needs to be protected. It also establishes a program for the rehabilitation of natural habitats and maintenance of viable populations. However, when applying this Act, ownership and any other property rights must be respected.

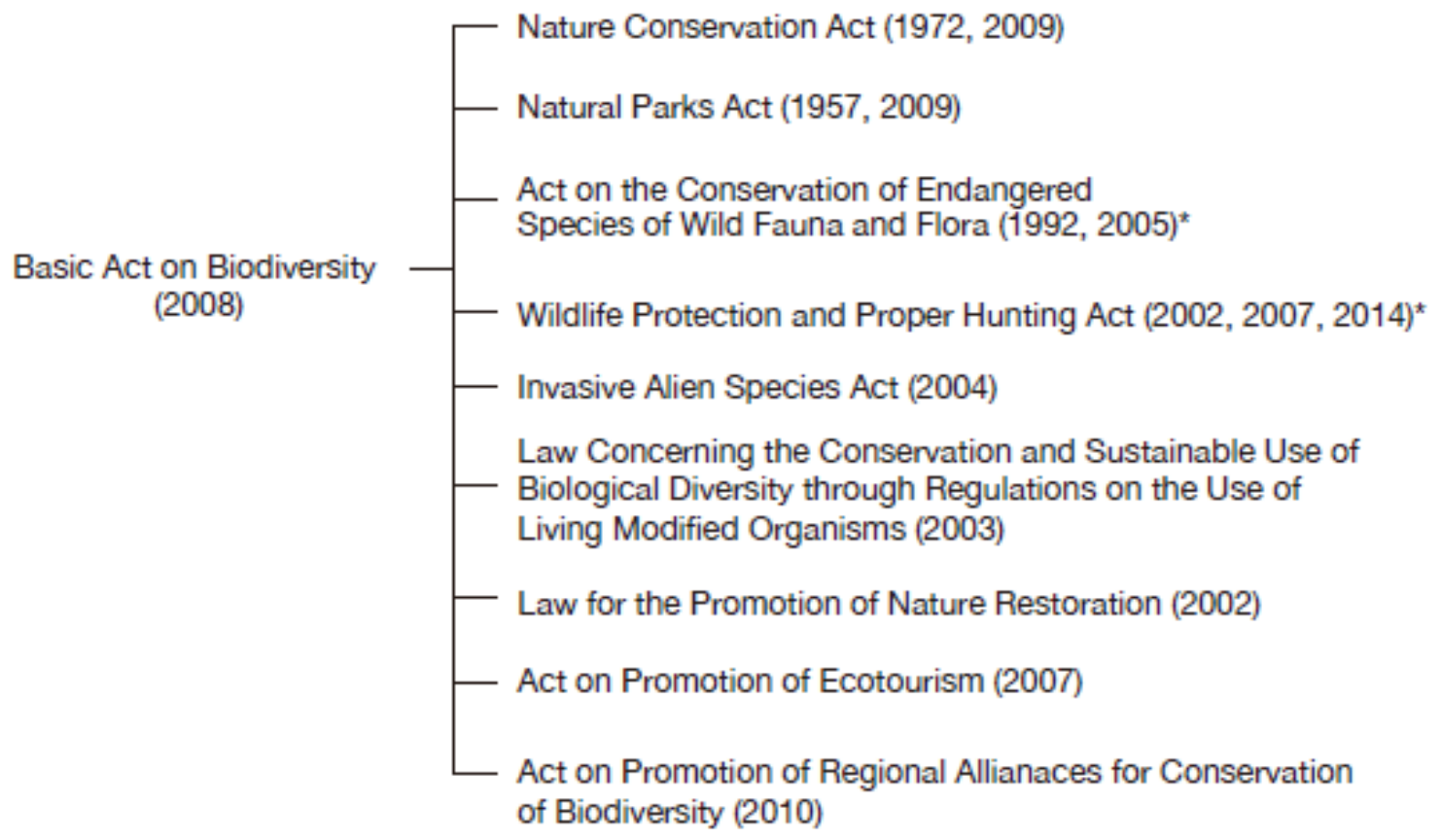

Figure 2. The structure of Japanese laws on biodiversity. Basic Act defines the fundamental policy of the Japanese government for conserving biodiversity. Practical policies and strategies are described in the 9 specific acts. Asterisks show the Acts that are highlighted in this study.

This act has been criticized by specialists at least for the following two points (The Nature Conservation Society of Japan 2010):

1. Since Endangered Species are designated by Cabinet Order without hearing the opinions of specialists, scientific priorities may not be sufficiently considered. For instance, although the Amami rabbit (Pentalagus furnessi), the Bonin flying fox (Pteropus pselaphon), a subspecies of Ryukyu flying fox (Pteropus dasymallus daitoensis), and two subspecies of the leopard cat (Prionailurus bengalensis iriomotensis and P. b. euptilurus) are designated as Endangered Species 
under this act, 24 other mammalian species ranked VU, EN or CR are still not being adequately considered for endangered status. It is worse still that 20 of the 24 species are endemic to Japan (Table 1), and arguably these endemics should be given the highest conservation priority in order to support conserving biodiversity on a global level.

Table 1. List of endemic terrestrial species in Japan for which conservation status is ranked [VU: vulnerable], [EN: endangered], [CR: critically endangered], or [DD: data deficient].

\begin{tabular}{|c|c|c|c|c|}
\hline Order & Family & Species & English name & Status \\
\hline \multicolumn{5}{|c|}{ Carnivora } \\
\hline & Mustelidae & & & \\
\hline & & Martes melampus (Wagner, 1840) & Japanese marten & VU \\
\hline \multicolumn{5}{|c|}{ Chiroptera } \\
\hline & Rhinolophidae & & & \\
\hline & & Rhinolophus pumilus Andersen, 1905 & \multirow{2}{*}{$\begin{array}{l}\text { Okinawa Little Horseshoe Bat } \\
\text { Yaeyama Little Horseshoe } \\
\text { Bat }\end{array}$} & CR \\
\hline & & Rhinolophus perditus Andersen, 1918 & & EN \\
\hline & Vespertilionidae & & & \\
\hline & & $\begin{array}{l}\text { Myotis yanbarensis Maeda and } \\
\text { Matsumura, } 1998\end{array}$ & Yanbaru Whiskered Bat & CR \\
\hline & & Myotis pruinosus Yoshiyuki, 1971 & Blackish Whiskered Bat & EN \\
\hline & & Pipistrellus endoi Imaizumi, 1959 & Endo's Pipistrelle & EN \\
\hline & & Eptesicus japonensis Imaizumi, 1953 & Japanese Northern Bat & EN \\
\hline & & Miniopterus fuscus Bonhote, 1902 & $\begin{array}{l}\text { East-Asian Little Bent-winged } \\
\text { bat }\end{array}$ & EN \\
\hline & & $\begin{array}{l}\text { Murina ryukyuana Maeda and } \\
\text { Matsumura, } 1998\end{array}$ & Ryukyu Tube-nosed Bat & EN \\
\hline & & $\begin{array}{l}\text { Nyctalus furvus Imaizumi and Yoshiyuki, } \\
1968\end{array}$ & Japanese Little Noctule & VU \\
\hline & & Murina tenebrosa Yoshiyuki, 1970 & Tsushima Tube-nosed Bat & DD \\
\hline & Pteropodidae & & & \\
\hline & & Pteropus pselaphon Layard, 1829* & Bonin Flying Fox & CR \\
\hline \multicolumn{5}{|c|}{ Molossidae } \\
\hline & & Tadarida latouchei Thomas, 1920 & Oriental Little Free-tailed Bat & DD \\
\hline & Hipposideridae & & & \\
\hline & & Hipposideros turpis Bangs, 1901 & Bang's Leaf-nosed Bat & EN \\
\hline \multicolumn{5}{|c|}{ Lagomorpha } \\
\hline & Leporidae & & & \\
\hline & & Pentalagus furnessi (Stone, 1900)* & Amami Rabbit & EN \\
\hline \multicolumn{5}{|c|}{ Rodentia } \\
\hline & Muridae & & & \\
\hline & & Diplothrix legata (Thomas, 1906) & Ryukyu Long-furred Rat & EN \\
\hline & & Tokudaia muenninki (Johnson, 1946) & Okinawa Spiny Rat & CR \\
\hline & & Tokudaia osimensis (Abe, 1933) & Amami Spiny Rat & EN \\
\hline & & $\begin{array}{l}\text { Tokduaia tokunoshimensis Endo and } \\
\text { Tsuchiya, } 2006\end{array}$ & Tokunoshima Spiny Rat & EN \\
\hline \multicolumn{5}{|c|}{ Soricomorpha } \\
\hline & Talpidae & & & \\
\hline & & $\begin{array}{l}\text { Mogera uchidai (Abe, Shiraishi and Arai, } \\
\text { 1991) }\end{array}$ & Senkaku Mole & CR \\
\hline & & $\begin{array}{l}\text { Mogera etigo Yoshiyuki and Imaizumi, } \\
1991\end{array}$ & Echigo Mole & EN \\
\hline & Soricidae & & & \\
\hline & & Crocidura orii Kuroda, 1924 & Orii's Shrew & EN \\
\hline
\end{tabular}


2. Since ownership and other property rights must be respected, the Minister may hesitate to establish natural habitat protection areas. Even the above four Endangered Species have no natural habitat protection areas. Furthermore data on two endemic species are still too deficient to consider their conservation status, although the national government has a responsibility to monitor them.

"Wildlife Protection and Proper Hunting Act". The Japanese version is published in on the following website: http://law.e-gov.go.jp/htmldata/H14/H14HO088.html. This act is aimed at ensuring wildlife protection and proper hunting in order to contribute to maintaining biodiversity, conserving living environments, and developing agriculture, forestry, and fisheries. This act targets wild mammals and birds. In addition to various regulations for hunting and taking of wildlife, this act requests the national and local governments to formulate and implement wildlife protection project plans. Under this act a local government may establish a "Specified Wildlife Conservation and Management Plan" to manage a local population which is either overabundant or vulnerable. The local government can be allowed to relax the regulation of hunting and other taking of animals. Many local governments are keen to control local populations of sika deer or wild boars which damage agricultural products and/or forests (see a later section for details).

In addition, Japanese animals and plants can be conserved as "Natural monuments" under the

Tabla 2. List of Japanese native terrestrial mammalian species or subspecies that are designated as "Natural monument". Local populations designated as "Natural monument" are not listed, because their conservation status is unclear. Abbreviations of conservation status are as follows: C: common; LP: threatened local population; R: rare; NT: nearly threatened; VU: vulnerable; EN: endangered; CR: critically endangered; EX: extinct; DD: data deficient.

\begin{tabular}{|c|c|c|c|c|}
\hline & Latin name & English name & $\begin{array}{l}\text { Conservation } \\
\text { status }\end{array}$ & $\begin{array}{l}\text { Endemism } \\
\text { level }\end{array}$ \\
\hline \multirow[t]{4}{*}{$\begin{array}{l}\text { Natural monument } \\
\text { (special) }\end{array}$} & Capricornis crispus (Temminck, 1845) & $\begin{array}{l}\text { Japanese } \\
\text { serow }\end{array}$ & LP & species \\
\hline & Lutra lutra (Linnaemus, 1758) & River otter & EX & not endemic \\
\hline & $\begin{array}{l}\text { Prionailurus bengalensis iriomotensis } \\
\text { (Imaizumi, 1967) }\end{array}$ & Iriomote cat & CR & subspecies \\
\hline & Pentalagus furnessi (Stone, 1900) & Amami rabbit & EN & genus \\
\hline \multirow[t]{9}{*}{ Natural monument } & Glirulus japonicus (Schinz, 1845) & $\begin{array}{l}\text { Japanese } \\
\text { dormouse }\end{array}$ & NT & species \\
\hline & Diplothrix legata (Thomas, 1906) & $\begin{array}{l}\text { Ryukyu long- } \\
\text { furred rat }\end{array}$ & EN & genus \\
\hline & Tokudaia muenninki (Johnson, 1946) & $\begin{array}{c}\text { Okinawa spiny } \\
\text { rat }\end{array}$ & CR & genus \\
\hline & Tokudaia osimensis (Abe, 1933) & $\begin{array}{l}\text { Amami spiny } \\
\text { rat }\end{array}$ & EN & genus \\
\hline & $\begin{array}{l}\text { Tokduaia tokunoshimensis Endo and } \\
\text { Tsuchiya, } 2006\end{array}$ & $\begin{array}{l}\text { Tokunoshima } \\
\text { spiny rat }\end{array}$ & EN & genus \\
\hline & $\begin{array}{l}\text { Prionailurus bengalensis euptilurus } \\
\text { (Elliot, 1871) }\end{array}$ & $\begin{array}{l}\text { Tsushima } \\
\text { leopard cat }\end{array}$ & CR & subspecies \\
\hline & $\begin{array}{l}\text { Martes melampus tsuensis (Thomas, } \\
\text { 1897) }\end{array}$ & $\begin{array}{l}\text { Tsushima } \\
\text { marten }\end{array}$ & VU & subspecies \\
\hline & $\begin{array}{l}\text { Pteropus dasymallus dasymallus } \\
\text { Temminck, } 1825\end{array}$ & $\begin{array}{l}\text { Erabu flying } \\
\text { fox }\end{array}$ & CR & subspecies \\
\hline & $\begin{array}{l}\text { Pteropus dasymallus daitoensis } \\
\text { Kuroda, } 1921\end{array}$ & $\begin{array}{l}\text { Daito flying } \\
\quad \text { fox }\end{array}$ & CR & subspecies \\
\hline
\end{tabular}

"Act on Protection of Cultural Properties". Nine species and 5 subspecies of Japanese mammals are designated as "Natural monuments" (Table 2). However, the effects of this act are limited, because its purpose is to maintain the situation of the "Natural monument". The act does not request national or local governments to take conservation actions so as to improve the situation for wildlife. 


\section{Conservation of endangered mammals}

\section{The Amami rabbit Pentalagus furnessi (Stone, 1900)}

The Amami rabbit is a primitive, short-eared rabbit which is endemic to Japan and that has evolved in an insular environment without native mammalian predators (Figure 3; Yamada and Cervantes 2005; Yamada 2008, 2009). It is distributed only on two small islands (Amami-ohshima Isl. and Tokuno-Shima Island) in Kagoshima Prefecture located in southern Japan. Using fecal pellet counts and resident surveys, the number of rabbits is estimated at 2000 to 4800 on Amami-ohshima Isl. in 2003 and 100 to 200 on Toku-no-Shima Island in 2004 (Sugimura and Yamada 2004). The size of its distributional range, as estimated by fecal pellet counts during 1992 to 1994 , is $370.28 \mathrm{~km}^{2}$ (52\% of the Island) on Amami-ohshima Isl. and $32.97 \mathrm{~km}^{2}$ (13\%) on Tokuno-shima Island. This represents a 20 to $40 \%$ decline in the area inhabited on Amami-ohshima Island in 1992 to 1994 compared to that estimated in 1974 and 1977 (Yamada 2009). In 1921, the Japanese government assigned the Amami rabbit to "natural monument" status which prevented it from being hunted. Then in 1963 , it was changed to a "special natural monument" which prevented it from being hunted and trapped, as well. MOE designated the Amami rabbit as a National Endangered Species in 2004.

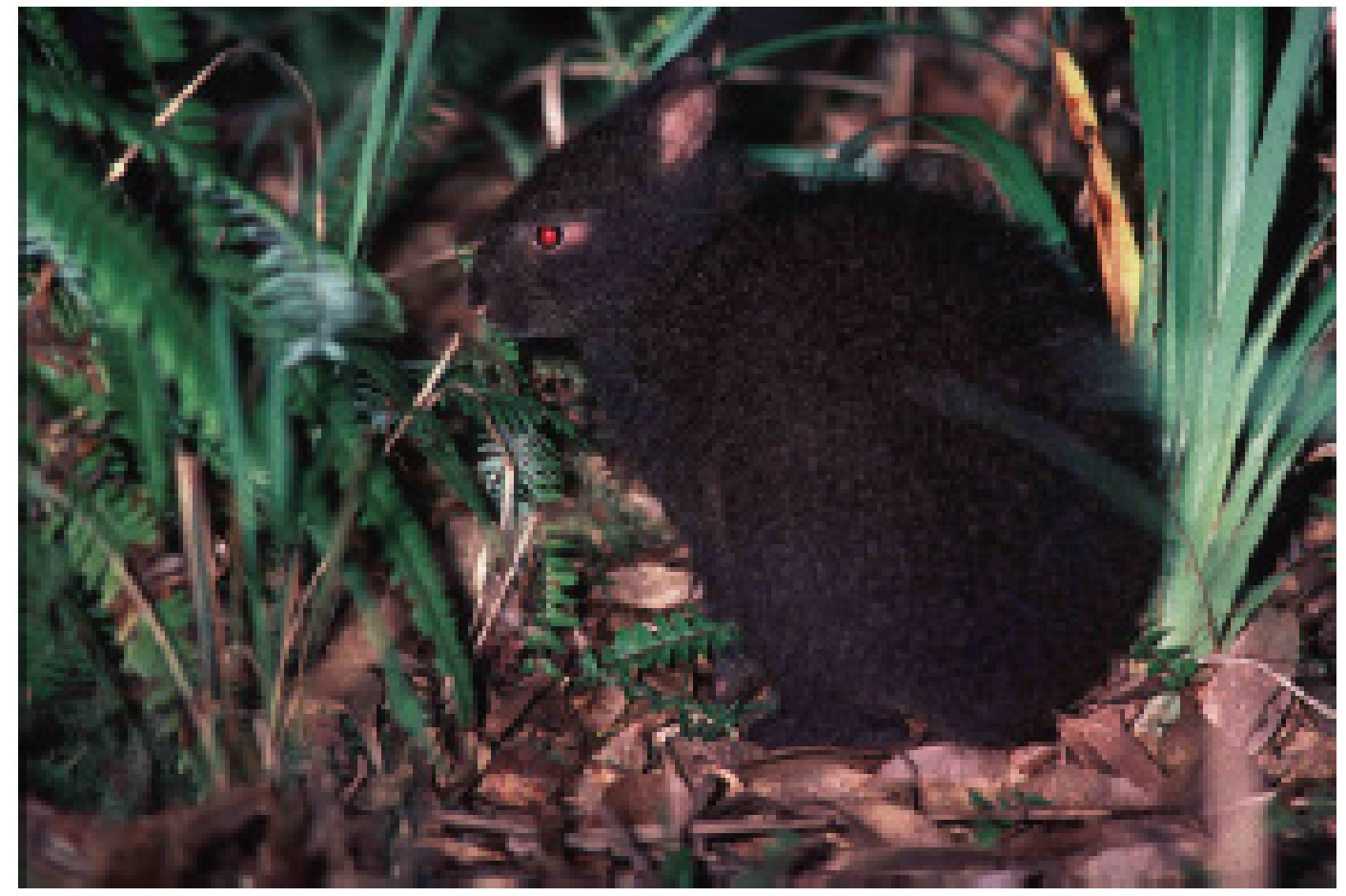

Figure 3. The Amami rabbit Pentalagus furnessi (Stone, 1900) on Amami-ohshima Island. (Photo by H. Katsu).

The Amami rabbit prefers a habitat of both mature and young forests, which provide food, nest sites and shelters. Habitat destruction, such as forest clearing for commercial logging, agricultural development, and residential areas, is the most detrimental activity for rabbits. Hunting and trapping were also causes of decline in their numbers. Furthermore, invasive alien predators, the small Indian mongoose (Herpestes auropunctatus), together with feral dogs and cats, have seriously damaged the rabbit population on Amami-ohshima Island. The mongoose was released onto this island in 1979. They were expected to control the population of a local venomous snake (Protobothrops flavoviridis), but the control program was in vain. They did not show any predation effect on the snake, while they have made several negative impacts on native species, especially on Amami rabbits (Yamada et al. 2009).

Suggested conservation work includes habitat restoration and predator population control. 
A new program of mongoose eradication was restarted in 2005 on Amami-ohshima Island under the "Invasive Alien Species Law." The subsequent decrease of the mongoose population and the recovery of the Amami rabbit population are recently recognized (Fukasawa et al. 2013; Watari et al. 2013). Predation by feral cats and road kills are the next most important issues, and habitat restoration and the connection of isolated habitats should also be considered. Restricting logging would help to keep more forest available for the rabbits. However, we cannot legally stop the logging in the rabbit habitats for their conservation, because MOE does not yet designate any area on Amami-ohshima Island and Toku-no-Shima Island as "natural habitat protection area" under the "Act on Conservation of Endangered Species of Wild Fauna and Flora." Since both islands are a candidate for designation of an Amami and Ryukyu World Natural Heritage Site, a wise use of forest and conservation plan for the rabbits' habitats is under discussion as a most urgent issue.

The leopard cat (Prionailurus bengalensis iriomotensis and P. b. euptilurus)

The leopard cat (Prionailurus bengalensis) has the largest distribution among the small cats in Asia, ranging from Siberia, China, Korea, Japan, southeast Asia to Indonesia and is divided into ten or more subspecies. Two subspecies of this cat occur on two southern islands of Japan; the Iriomote cat Prionailurus bengalensis iriomotensis (Imaizumi, 1967) on Iriomotejima Island (ca. 284 $\mathrm{km}^{2}$ ) and the Tsushima leopard cat P. b. euptilurus (Elliot 1871) on Tsushima Islands (ca. $710 \mathrm{~km}^{2}$ in total). Both are small-sized felids with body weights of $4-4.5 \mathrm{~kg}$ for males and 3-3.5 kg for females.

The Iriomote cat is strictly endemic to Iriomotejima Island in the southern part of the Ryukyu Archipelago (Figure 4). Within the Japanese territory, the Tsushima leopard cat occurs only on Tsushima Islands. Both cats are listed as Critically Endangered in the Red List of the MOE (2012), and the Iriomote cat is listed as a Critically Endangered Subspecies in the Red List of IUCN (2008). The Iriomote cat was designated as a Special Natural Monument (1977) and as a National Endangered Species (1994). The Tsushima leopard cat was also designated as a Natural Monument (1971) and a National Endangered Species (1994).

Iriomote cat numbers have been estimated as 83-109 in 1984 and 99-110 in 1994. Although no clear tendency of decrease or increase was recognized (Ministry of the Environment of Japan 1985; Japan Wildlife Research Center 1994), the survey in 2005-2008 suggested that the population in the coastal lowland showed a decrease of 8-9 \% (University of the Ryukyus 2008). The Tsushima leopard cat was reported to inhabit all of the Ryukyu Islands with a population of 200 to 300 until the 1970's (Yamaguchi and Urata 1976), although details were not clear. Recently the population size was estimated at 98-142 in 1988, 92-129 in 1997 and 83-115 in 2005 (Japan Wildlife Research Center 1988; Ministry of the Environment and Nagasaki Prefecture 1997, Japan Wildlife Research Center 2005). The population is declining at the rate of about $10 \%$ every 10 years (Japan Wild life Research Center, 2005).

Habitat loss (deforestation) and road kills are major threats for these two subspecies (Izawa et al. 2009). A large part of both islands are covered with forests. The large area of inner mountainous forests on Iriomotejima Island is protected and managed as National Forest and National Park by the national government of Japan. However, in the northern coastal lowlands of the island deforestation through land conversion for agriculture, construction of roads and tourist facilities, and the loss of the forests through road widening have all occurred. Forest protection and management are relatively weak on Tsushima; one-third of the forests are artificial plantations and most forests are private property without any regulation against deforestation.

Frequent road kills directly affect the cat populations on each island. Traffic accidents killed 34 
cats from 2000 to 2013 (2.4 cats/year) on Iriomotejima Island and 59 cats from 2000 to 2013 (4.2 cats/year) on Tsushima Island. The recent increase of tourists in Iriomotejima Island has resulted in an increase of traffic volume. Moreover, road widening may cause higher driving speeds on both islands. Considering the small population sizes (ca. 100 each), the mortality caused by road kills should not be ignored.

Other threats are derived from invasive animals: predation by dogs, competition with feral cats (Watanabe et al. 2003), and the spread of diseases such as Feline immunodeficiency virus from domestic cats (Nishimura et al. 1999).

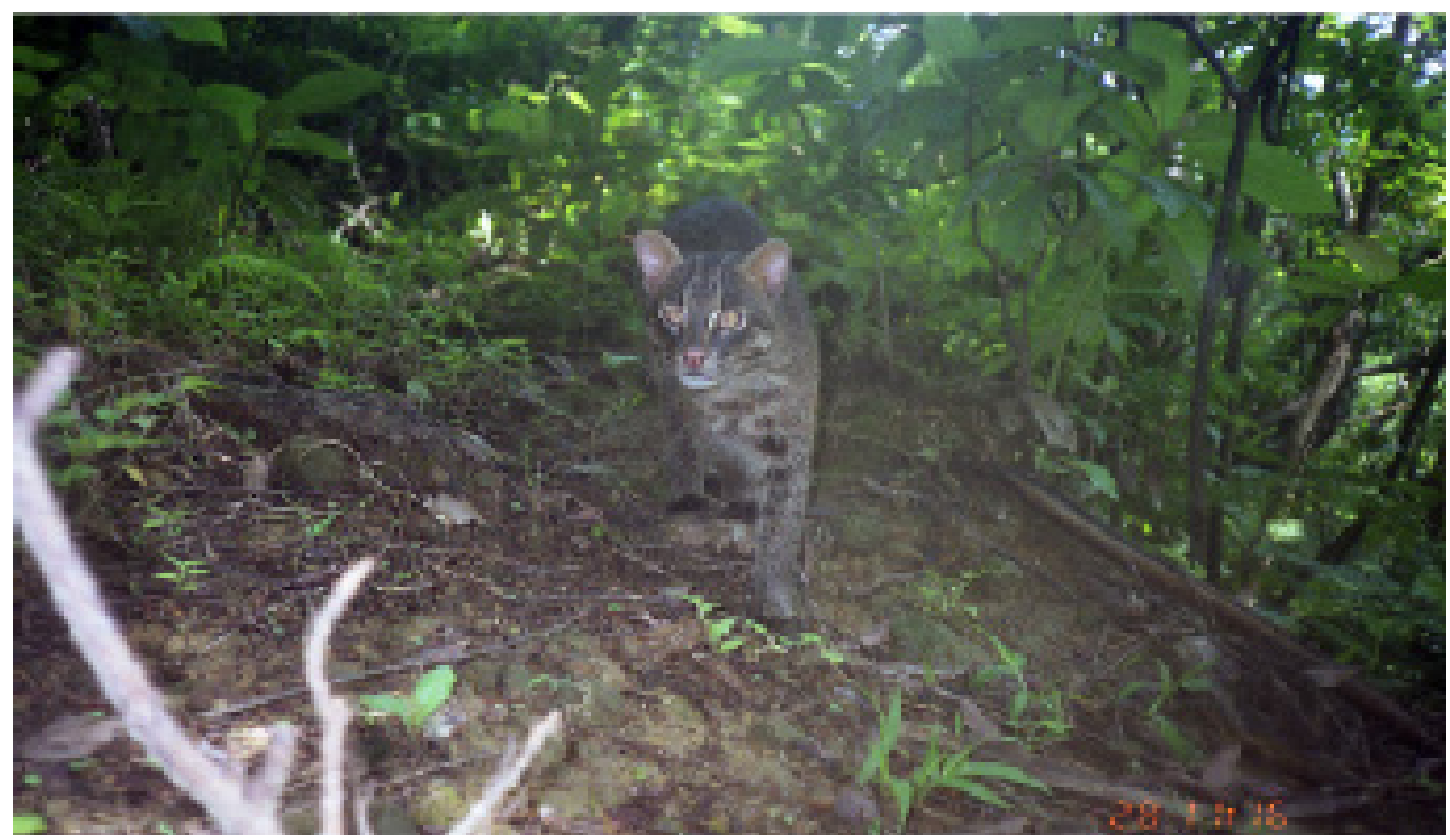

Figure 4. An Iriomote cat Prionailurus bengalensis iriomotensis (Imaizumi, 1967) walking in the subtropical forest of Iriomotejima Island. This photo was taken by the Laboratory of Mammal Ecology, University of the Ryukyus.

A recent and future possible threat for the Iriomote cat is the increase in tourists and changes of tourism style. The style of tourism has changed from large groups using a coach to "eco-tour." Now more tourists want to enter the island interior by using a canoe and enjoy bush-walking. These impacts on interior mountainous forests and the ensuing disturbance to wild animals are severe enough to cause concern (Japan Wild life Research Center 2005; University of the Ryukyus 2008).

Conservation activities are conducted by the national and local governments and NGO's, etc. (Izawa et al. 2009). Since hunting is prohibited for the felids and poaching is rare in Japan, conservation issues focus on habitat improvement including elimination of invasive species and traffic peril. Although the government has designated some part of the cat's habitat as nature reserves or a national park, the size of these areas is insufficient. The Wildlife Conservation Center of MOE (WCC) on the Iriomotejima Isl. and the Tsushima Islands plays an important role in conservation of the cats. The Forestry Agency of the Japanese government also has conducted a photo-trapping program to monitor the cat population in the national forest since 1993.

Measures to prevent road kills started on Iriomotejima Isl. by a local government and the Iriomote WCC. About 100 underpasses for cats were constructed along a road of about $50 \mathrm{~km}$. Iriomote cats and other animals (including prey animals of Iriomote cats) were confirmed to use them by employing camera traps (Okamura et al. 2003; University of the Ryukyus, 2008). Road signs and speed bumps were provided in order to catch driver's attention and reduce driving speed. Some educational programs have also been done for drivers. 
Measures to reduce the number of feral cats have been done by NGO's on the Iriomotejima Island. The program by a NGO consists of veterinarians trapping feral cats, removing them from the island, keeping them in a shelter, and seeking a new owner. This program is effective in reducing the number of feral cats. The NGO carries out an educational program for cat owners and promotes breeding control and vaccination. Although a similar program is conducted on the Tsushima Islands, it is more difficult to reduce the number of feral cats because of larger area and more abundant feral and house cats.

The population of Iriomote cats is thought to be almost stable. However, habitat conditions along the coastal area have been degraded by the growth of tourism and road development in the last ten years, and further degradation is anticipated. Measures to reduce road kills, a guideline for ecotourism, and lowland habitat management are required. Similar conservation activities have been conducted for the populations of Tsushima leopard cats. However, more effort is required for them in comparison with the Iriomote population.

Flying foxes. Two species of Pteropodidae occur in Japan. These are both medium-sized Pteropus species that occur at the northern limit of Pteropodidae distribution. One is the Bonin flying fox (Pteropus pselaphon Layard 1829) which is endemic to the Ogasawara Islands (5 islands) in southern Japan (Yoshiyuki 1989; Inaba et al. 2002; Suzuki and Inaba 2010). The other is the Ryukyu flying fox (Pteropus dasymallus) ranging from the Ryukyu Archipelago to two small islands in Taiwan, and possibly to a few northern Philippine islands. The Ryukyu flying fox is divided into four subspecies (Yoshiyuki 1989; Kinjo and Nakamoto 2009). Two of them are common, but the other two are endangered. Of most concern is the Daito flying fox, a subspecies (Pteropus dasymallus daitoensis Kuroda 1921; Figure 5) that is endemic on the Daito Islands (2 small islands).

The Bonin flying fox is listed as Endangered and the Daito flying fox as Critically Endangered in the Red List of MOE (2012). In addition, the Bonin flying fox is listed as Critically Endangered and the Ryukyu flying fox as Near Threatened in the Red List of IUCN (2008). The Bonin flying fox was designated as a Natural Monument (1969) and as a National Endangered Species (2009). The Daito flying fox was designated as a Natural Monument (1973) and a National Endangered Species (2004).

Little information is available on the population dynamics of these flying foxes, partly because these nocturnal and volant species are very hard to survey. The Bonin flying fox on Chichijima Island (the largest island within its distribution) was considered to be extinct in the 1970's, but they recolonized in the 1980's (Inaba et al. 2002). Population size has slowly increased since then and is estimated at 100 to150 individuals by recent surveys (Kinjo and Izawa 2009; Suzuki and Inaba 2010). On the other hand, the population on Hahajima Island (the second largest island) greatly decreased from more than 100 in 1960's to a few individuals in 2000's. As it is hard to access other islands in their distribution, information is very limited. The population on Minami-Iwo-to Island was estimated at more than 100 in 1982 and 2007 (Suzuki 2008; Kinjo and Izawa 2009; Suzuki and Inaba 2010).

For the Daito flying fox, information on their status is even less. The Daito Isls. have a unique history of human activity. These islands have been inhabited since 1900, and almost all natural forests were cut and turned into farmland. Then many native animals including endemic species went extinct. The population of the Daito flying fox may have drastically decreased, although the original population size is unknown. Recent estimation showed that population size was about 300, and it has looked stable in the last 10 years (Izawa et al. unpublished).

These two species are frugivores, but also feed on nectar and leaves. Important habitat components are the feeding tree and the roosting (resting) trees. Unlike the small Chiroptera, flying foxes roost in tree canopies in daytime. As the habitats of both species are oceanic islands, there are no natural enemies for them. The only natural harm to their populations is the effect of typhoons (Nakamoto et al. 2007; 2011). Typhoons cause direct mortality and also cause food shortages by 
damaging food plants. For the conservation of flying foxes, various plants should be ensured for their food supply and roosting sites.

Threats for the flying foxes are habitat destruction such as deforestation, disturbance of roosting sites by tourism, and predation by alien predators such as domestic cats. Especially for the Bonin flying fox, which forms permanent colonies and tends to use fixed roosting sites (Sugita et al. 2009), human disturbance to these roosting sites is a serious threat. Additionally, these bats conflict with farmers for commercial fruits. Although farmers do not kill flying foxes directly, they are accidentally killed by orchard nets which farmers set to prevent birds and flying foxes from accessing fruit crops.

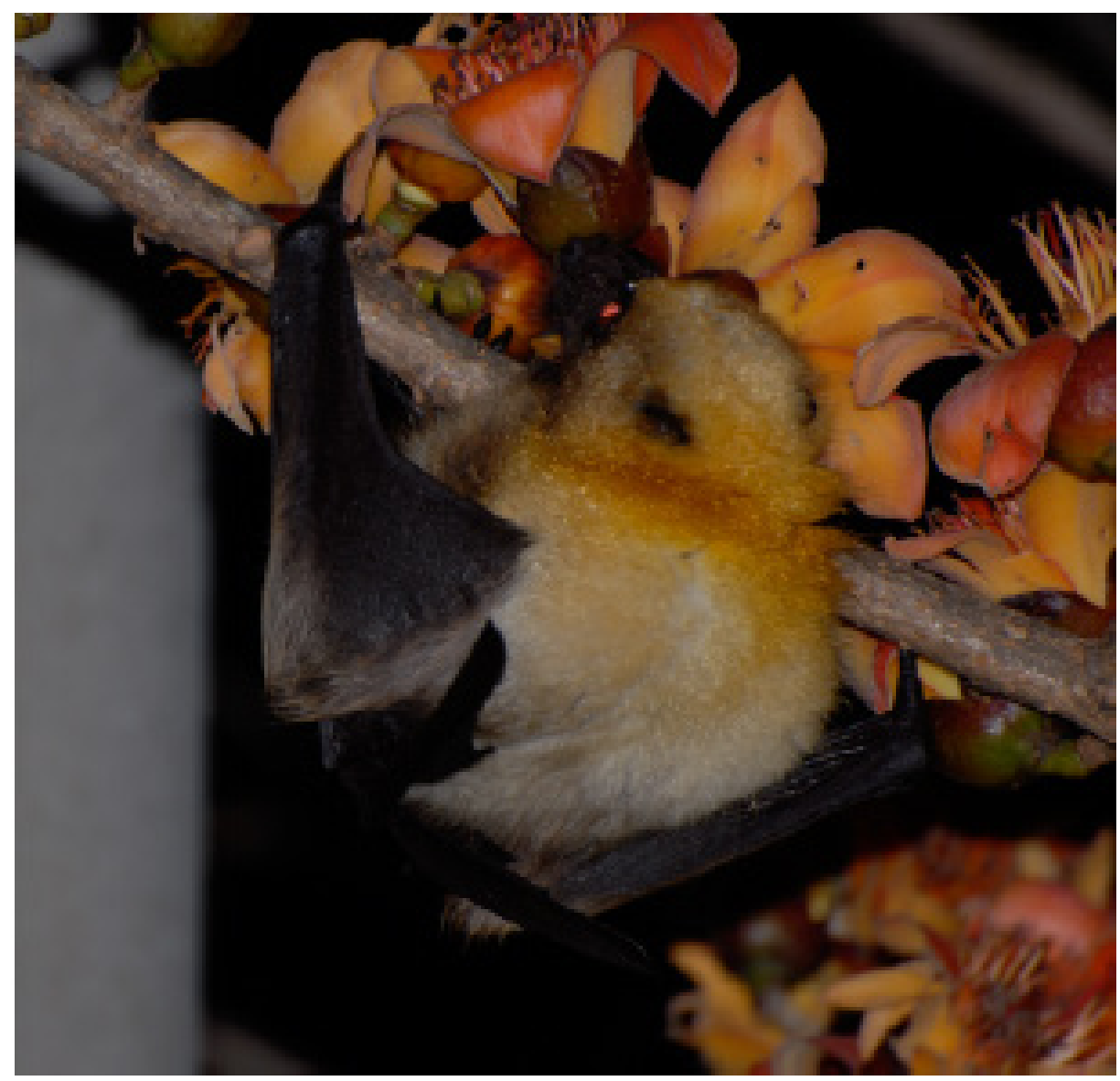

Figure 5. A male Daito flying fox (Pteropus dasymallus daitoensis Kuroda, 1921) feeding on the nectar of the red silk-cotton tree; photographed by Masako Izawa.

The Ogasawara Islands were registered as a world natural heritage site in 2011. Conservation of relatively intact communities is conducted by MOE, the Forestry Agency, the local government and NGO's. In the process of preparation for designation of such reserves, many projects were conducted for eliminating alien species. A project to control the population of feral cats was also done and still continues. It gives steady favorable results so far. On the other hand, the designation of world natural heritage status has brought in more active tourism. This has caused the disturbance of roosting sites and habitat reduction of the Bonin flying fox. For the Daito flying fox, human caused damage to its population is not so serious now. A most serious concern is strong typhoons which reach these islands several times a year. Provision of food after typhoon attacks is a most important conservation measure. Other actions needed to maintain natural habitats are stopping the enlargement of farmlands and eliminating the invasive pest insects on agricultural plants. 
Management of overabundant ungulate populations. Two ungulates, Sika deer (Cervus nippon) and wild boar (Sus scrofa), markedly increased in numbers and extended their geographic distribution in Japan during the last few decades. The range of sika deer and wild boar expanded by 1.7 times and 1.3 times, respectively from 1978 to 2003 (Biodiversity Centre of Japan, MOE). The number of sika deer harvested has increased markedly from the beginning of the 1990s to the present: from 41,949 in 1990 to 363,100 in 2010, corresponding to a 9-fold increase with a mean annual increase rate of $9.8 \%$ during the last 20 years. The number of wild boar harvested has also increased markedly from 70,102 in 1990 to 477,000 in 2010, corresponding to a 7-fold increase with a mean annual increase rate of $10 \%$ during the last 20 years (MOE). These data clearly show a dramatic increase in numbers of these two species in Japan. The rapid increase in the large ungulates may have had multiple causes associated with changes in socio-economic and natural environments. These include elimination of wolves, clear-cutting of forests, increased pasture acreage, increased abandonment of cultivated areas, decrease in the hunter population, and strengthening enforcement to prevent poaching, all of which have most likely contributed to the expansion of distribution and the increase in population size of these two species. In addition, there were no severe winters during the last 25 years, which may have contributed to an increase in the rate of population growth. The decrease of human presence in mountain and rural areas has also favored ungulate populations.

The current wildlife management system in Japan is based on"the Specified Wildlife Conservation and Management Plan" (prefecture-determined management plan system) under "Wildlife Protection and Proper Hunting Act", which was revised in 1999. This revision of the law in 1999 was the beginning of scientific management of wildlife in Japan. Most prefectural governments now have sika deer and wild boar populations incorporated into their management plans. Prefectural governors may designate a certain population of wildlife showing either marked increases or decreases as "Specified Wildlife," and establish a management plan. Under the planning system a local government can extend hunting periods and relax regulation of harvest numbers per day for an overabundant wildlife population, or regulate hunting, incorporate measures to preserve natural habitat, and prevent wildlife conflict for a threatened population, by taking long-term stability and viability of the regional population into consideration.

For damage control, the "Act on Special Measures for Prevention of Damage Related to Agriculture, Forestry and Fisheries Caused by Wildlife (Act on municipality-determined damage control plan system)" was established by the Ministry of Agriculture, Forestry and Fisheries (MOA) in 2007. This act intends to reinforce efforts of municipalities and hunters through subsidies from MOA. Damage control programs are set for about $90 \%(1331 / 1500)$ of municipalities which suffer damages from wildlife, and half of those municipalities (674) have organized culling programs in 2013 (MOA).

A working group of the Mammal Society of Japan reviewed the management plans for sika deer populations by prefectural governments, and pointed out the following problems (Uno et al. 2007):

- High possibility of underestimation of population size

- Difficulty of population reduction due to expanding ranges

- Drastic decrease in the population of hunters

- Lack of programs for sustainable resource management

- Lack of adaptive management systems that incorporate science in wildlife management policies

- Lack of large scale management systems in cooperation with neighboring prefectural governments. 
The 1999 version of "Wildlife Protection and Proper Hunting Act" includes both elements of wildlife conservation ( $\approx$ protection) and management. However, relatively speaking, it is biased toward the role of conservation. Thus further revision of the Act was requested adding the viewpoint of pest control. To review the "Wildlife Protection and Hunting Law", MOE organized a panel consisting of wildlife professionals to discuss how wildlife management should be organized in Japan. Main points of the review were as follows:

- The "Wildlife Protection and Proper Hunting Act" should be changed so as to explicitly include the practice of wildlife management and professional approaches to pest control.

- There is a need to clarify the role of national, prefectural, and municipal governments, and to construct a cooperative structure among them as well as with NGOs.

- A system to promote effective culling of over-abundant species must be constructed.

- Legal measures for wildlife management need to be authorized.

- For animals that are widely distributed, increasing in numbers, and thereby causing damages, the role of the national government might be important for evaluating the situation and providing leadership for nationwide management solutions.

- The promotion of hunting as a method of population control where appropriate should be discussed.

- The scientific basis for management must be promoted, as well as the public awareness of wildlife management.

The "Wildlife Protection and Proper Hunting Act" was revised again as the "Wildlife Protection and Management, and Proper Hunting Act" on March 11, 2014, in order to further emphasize the importance of management of wildlife. Under the revised law the Minister of MOE can designate a wildlife population as "Specified Wildlife" that should be managed intensively and extensively, and the national or prefectural governments can relax existing regulations for hunting and capture of wildlife under a plan authorized by the law. In particular, organizations that are empowered under the authorized plan can skip the official procedures required to capture designated wildlife, and night shooting can be allowed under specified conditions. In addition, a certificated business operator system is introduced in the revised law. Persons who apply to implement a population control project can be certificated for their skills and knowledge in capturing wildlife by the governor of prefectures based on a specified standard. The revised law is expected to enhance the number of sika deer and wild boars harvested, and thereby reduce their population sizes to a half of the present size for the next 10 years.

\section{Conclusions}

The Japanese mammalian fauna is rich and includes many endemic species. Therefore, the Japanese government has a high degree of responsibility to conserve its mammalian fauna, because the extinction of the endemic species in Japan directly results in significant reduction of biodiversity in the world. The Japanese legal system concerned with biodiversity appears to be well organized (Figure 2). However, its implementation is not sufficient. For instance, although four species (or subspecies) are designated as Endangered Species and some conservation measures have been carried out, 20 endemic species ranked VU, EN or CR are still not being adequately considered for endangered status. Furthermore, although habitat loss poses a major threat in most cases, MOE frequently hesitates to establish natural habitat protection areas. Like other developed countries, Japan is distressed by damages caused by overabundant populations of some wildlife. Although the national and prefectural governments have been encouraging pest control by paying a reward to reduce the size of overabundant populations, it is not always easy 
to keep high culling pressure on those populations because of budget limitation and the decrease in the number of hunters. The reduction in the numbers of hunters is caused by aging of the population and excessive concentration of people into urban centers. In addition, Japan has a cultural problem. Japanese are traditionally a fish-eating people, and we rarely find game meat for sale in Japanese markets. Reformation of Japanese society may be required to solve the long term and complex problems with its wildlife.

\section{Acknowledgments}

We thank W. Z. Lidicker, Jr. for reading an early version of the manuscript and formulating valuable comments. We also thanks T. Alvarez-Castañeda for giving us a chance to summarize the current activities in conservation and management of Japanese mammals.

\section{Resumen}

Introducción. Ciento un especies de mamíferos terrestres nativos, con exclusión de Sirenia, Cetaceae, Phocidae y Otariidae, habitan o habitaron Japón, el $51.5 \%$ de ellas son endémicas, la mayoría de ellas pertencen a especies nativas de los bosques. Cuatro especies, el lobo, el zorro volador de Okinawa, el murciélago de Bonin, y la nutria de río japonesa se extinguieron durante la edad moderna. Esta relativa baja tasa de extinción de especies en Japón es probablemente debida a que la destrucción del bosque ha sido limitada en este pais. Alrededor de dos tercios del territorio japones todavía está cubierto por bosques (25.10/37.79 millones de hectáreas, el $66.4 \%$ a partir de 2011 de acuerdo con Agencia Forestal del Gobierno japonés). Sin embargo, el número de especies que estan clasificadas bajo un estado de conservación no es pequeña; cinco especies se clasifican "vulnerable" (VU), 15 "en peligro" (EN) y ocho "En peligro crítico" (CR). El número total de especies clasificadas en estas tres categorías es de 28 , y lo que representa un porcentaje del $28.9 \%$ (=28/97), el cual es el porcentaje de especies en categoria de conservacion más alto de en comparación con el estándar mundial. Esta situación puede ser causada por una amplia construcción de bosques artificiales de 1950 a 1970, época durante la cual muchos bosques naturales de Japón se talaron y fueron transformados a bosques artificiales.

Discusión y conclusiones. La proporción de los bosques naturales se redujo a alrededor del 40 \% de la superficie total de bosques en 2013. Las leyes más influyentes para la conservación de la vida silvestre y la gestión en Japón son la "Ley sobre la Conservación de Especies Amenazadas de Fauna y Flora Silvestres "y" Ley de Protección Caza Adecuada y Vida Silvestre ". El conejo de Amami (Pentalagus furnessi), el zorro volador de Bonin (Pteropus pselaphon), una subespecie zorro volador de Ryukyu (Pteropus dasymallus daitoensis), y dos subespecies de leopardo (Prionailurus bengalensis iriomotensis y P. b. Euptilurus) se conservan bajo "Ley sobre Conservación de Especies Amenazadas de Fauna y Flora Silvestres", mientras que la conservación de muchas especies terrestres endémicas que se clasifican en altas categorias de riesgo no son consideradas en las leyes japonesas. Recientemente se han desarrollado prácticas de gestión y manejo para las poblaciones sobreabundantes, como lo son el ciervo sika (Cervus nipón) y el jabalí (Sus scrofa) bajo la "Ley de Caza Adecuada y Protección de la Fauna".

\section{Literature Cited}

Diamond, J. M. 2005. Collapse: How Societies Choose to Fail or Succeed. Viking. New York, U.S.A.

Fukasawa, K., T. Miyashita, T. Hashimoto, M. Tatara, and S. Abe. 2013. Differential population responses of native and alien rodents to an invasive predator, habitat alteration and plant masting. Proceeding of the Royal Society B 280:177320132075 20132075.

Inaba, M., S. Takatsukı, K. Ueda, M. Izawa, H. Suzuki, and K. Horikosi. 2002. An urgent appeal for conservation of the Bonin flying fox, Pteropus pselaphon Layard, an endangered species. Japanese Journal of Conservation Ecology 7:51-61.

Izawa, M., T. Doi, N. Nakanishi, and A. Teranishi. 2009. Ecology and conservation of two endangered subspecies of the leopard cat (Prionailurus bengalensis) on Japanese islands. Biological Conservation 142:1884-1890.

Japan Wildife Research Center. 1988. Research Report on Environmental Habitat of the Tsushima leopard cat. Japan Wildlife Research Center. Tokyo, Japan. In Japanese. 
Japan Wildlife Research Center. 1994. Research Report on Environmental Habitat of the Iriomote cat. Japan Wildlife Research Center. Tokyo, Japan. In Japanese.

Japan Wildlife Research Center. 2005. Research Report on Environmental Habitat of the Tsushima leopard cat (2004). Japan Wildlife Research Center, Tokyo, Japan. In Japanese.

Kinso, K. And M. Izawa. 2009. Pteropus pselaphone Layard, 1829. Pp. 56-57 in The Wild Mammals of Japan. (Ohdachi, S. D., Y. Ishibashi, M. A. Iwasa, and T. Saito, eds.). Shoukadoh. Kyoto, Japan

Kinso, K., And A. Nakamoto. 2009. Pteropus dasymallus Temminck, 1825. Pp. 52-53 in The Wild Mammals of Japan (Ohdachi, S. D., Y. Ishibashi, M. A. Iwasa, and T. Saito, eds.). Shoukadoh. Kyoto, Japan.

Ministry of the EnVIRonment of Japan. 1985. Research report on environmental habitat and conservation of the Iriomote cat. Ministry of the Environment, Japan. Tokyo, Japan. In Japanese.

Ministry of the Environment and Nagasaki Prefecture. 1997. Research Report on Environmental Habitat of the Tsushima leopard cat. Ministry of the Environment. Japan, Tokyo. In Japanese.

Nakamoto, A., K. Kinjo, and M. Izawa. 2007. Food habits of Orii's flying-fox, Pteropus dasymallus inopinatus, in relation to food availability in an urban area of Okinawa-jima Island, the Ryukyu Archipelago, Japan. Acta Chiropterologica 9:237-249.

Nakamoto, A., A. Sato, K. Kinjo, And M. Izawa. 2011. Population growth of Orii's flying fox, Pteropus dasymallus inopinatus, on Okinawa-jima Island. Japanese Journal of Conservation Ecology 16:4553. In Japanese with English summary.

Nishimura, Y., Y. Goto, K. Yoneda, Y. Endo, T. Mizuno, M. Hamachi, H. Maruyama, H. Kinoshita, S. Koga, M. Komori, S. Fushuku, K. Ushinohama, M. Akuzawa, T. Watari, A. Hasegawa, and T. Tsujimoto. 1999. Interspecies transmission of feline immunodeficiency virus from the domestic cat to the Tsushima cat (Felis bengalensis euptilura) in the wild. Journal of Virology 73:7916-7921.

Ohdachi S. D., Y. Ishibashi, M. A. Iwasa, AND T. Saitoh. 2009. The Wild Mammals of Japan. Shoukadoh, Kyoto.

Okamura, M., M. Tatara, M. Izawa, T. Dol, N. Sakaguchi, T. Hedona, A. Gushikenn, and Y. Tamashiro. 2003. To stop the traffic accidents of the Iriomote cat. Proceedings of the 2nd Workshop of "Wildlife and Traffic" Pp. 67-74.

Sugimura, K., and F. Yamada. 2004. Estimating population size of the Amami rabbit (Pentalagus furnessi) based on fecal pellet counts on Amami Islands, Japan. Acta Zoologica Sinica 50:519-526.

Sugita, N., M. InABa, AND K. UEdA. 2009. Roosting pattern and reproductive cycle of Bonin flying foxes (Pteropus pselaphon). Journal of Mammalogy 90:195-202.

Suzukı, H. 2008. Report of the animals on Kita-iwo-to. Pp. 91-94. Branch Office of Tokyo Metropolitan Government. Tokyo, Japan. In Japanese.

Suzukı, H., AND M. INABA. 2010. Future of the flying guardian of forest and the islands. Iden, 64:61-67. In Japanese.

The Forestry Agency of Japanese Government. 2013. Annual report on forest and forestry in Japan.

The Nature Conservation Society of Japan. 2010. Ecological Review of Japanese Laws for Wildlife Conservation. Kohdansha. Tokyo, Japan. In Japanese.

UnIVERSiTy OF THE RYukyus. 2008. Research Report on Environmental Habitat of the Iriomote cat. University of the Ryukyus. Okinawa, Japan. In Japanese.

Uno, H., M. Yokoyama, H. Sakata, and the working group of sika deer management in Mammal Society of JAPAN. 2007. Current status of and perspectives on conservation and management for sika deer populations in Japan. Honyurui Kagaku (Mammalian Science) 47:25-38. In Japanese.

Watanabe, S., N. Nakanishi, and M. Izawa. 2003. Habitat and prey resource overlap between the Iriomote cat Prionailurus iriomotensis and introduced feral cat Felis catus based on assessment of scat content and distribution. Mammal Study 28:47-56.

Watari, Y., S. NishiJima, M. Fukasawa, F. Yamada, S. Abe, and T. Miyashita. 2013. Evaluating the "recoverylevel" of endangered species without prior information before alien invasion. Ecology and Evolution 3:4711-4721. 
Yamada, F., and F. A. Cervantes. 2005. Pentalagus furnessi. Mammalian Species 782:1-5.

YAMADA, F. 2008. A review of the biology and conservation of the Amami rabbit. Pp 369-377 in Lagomorph Biology, Ecology, and Conservation (Alves, P. C., N. Ferrand, and K. Hackländer, eds.). Springer. Berlin, Germany.

Yamada, F. 2009. Pentalagus furnessi (Stone, 1900). Pp. 204-205 in The Wild Mammals of Japan. (Ohdachi, S. D., Y. Ishibashi, M. A. Iwasa, and T. Saito, eds.). Shoukadoh, Japan.

Yamada, F., G. Ogura, and S. Abe. 2009. Herpestes javanicus (É. Geoffroy Saint-Hilaire, 1818). Pp. 264-266 in The Wild Mammals of Japan. (Ohdachi, S. D., Y. Ishibashi, M. A. Iwasa, and T. Saito, eds.). Shoukadoh, Japan.

Yamaguchi, T., And A. Urata. 1976. The Tsushima leopard cat. Pp.167-180 in Wildlife in Tsushima Islands (Biological Society of Nagasaki Prefecture ed.). Biological Society of Nagasaki Prefecture, Nagasaki. In Japanese.

YoshiYukı, M. 1 989. A systematic study of the Japanese Chiroptera. National Science Museum monographs 7:1-242.

Summited: October 8, 2014

Review: November10, 2014

Accepted: November 20, 2014

Associated editor: William Lidicker 
154 THERYA Vol. 6(1): 139-153 